\title{
Waders of Lake Cartma (The Systems of Coastal Lakes of the North Aral Sea, Kyzylorda, Kazakhstan)
}

\author{
N.S. Sihanova*1, I.I.Rahimov ${ }^{2}$ \\ ${ }^{1,2}$ Institute of Fundamental Medicine and Biology Federal State Autonomous Educational Institution of \\ Higher Education "Kazan (Volga region) Federal University", 18 Kremlevskaya St., Kazan, Russia, 420008, \\ Email: Muhtasar_08@mail.ru., Contact: +79274099233
}

Received: 21st October 2017 Accepted: 16th November 2017, Published: 31st December 2017

\begin{abstract}
Up to the 1960's, the system of lakes in the delta of the Syr Darya River and the Large Aral Sea have been a unified system of connections for the biocenosis. Birds, nesting here, as well as migrating to Siberia from wintering in North Africa, SouthWest Asia, choose this territory as the area for the rest, breaks, replenishment of reserves. The rapid fall of the Aral Sea level, due to the water stress of influent rivers the Syr Darya and the AmuDarya resulted in a decrease in the water area of the single terminal basin, and deterioration of the environmental situation in the Aral Sea region. Lake systems of the Syr Darya delta in 2012 were included in the list of wetlands of universal importance, protected by the international Ramsar Convention. Lake Cartma, until the last regression of the Aral Sea, was a floodplain on the eastern part of the reservoir. The materials of bird counts of Lake Cartma are presented in the article for the spring-summer season of 2017. Specialized surveys of avifauna have been carried out by authors since 2014. The lake's avifauna is represented by species of limnophiles, which are characterized by seasonal residence during migration and nesting. Most of the limnophiles of Lake Cartmaare waders, represented by 18 species. Nesting species prevailbyseasonality; other species visit the lake during the spring-autumn migrations and summer migrations. The only species, listed in the Red Book of the Republic of Kazakhstan, is the sociable plover, transient bird, noted during the spring counts.
\end{abstract}

Keywords: System of Lakes in the Syr Darya Delta, Lake Cartma, Wetlands, Waders, Seasonality of Residence, Ornitho-Faunistic Type.

\section{Introduction}

Scientific studies of the avifauna of the Aral Sea and the Syr Darya delta lake systems began in the second half of the XIX century [1]. Scientifically, the avifauna of this area has been surveyed quite fully [2]. The last regression of the Aral Sea, which began in the 1960's, resulted in change of the regional biodiversity [3]. The decrease in the water content of the SyrDarya River caused the regression of the Aral Sea as a single reservoir and divided into small parts. This led to a reduction in the number of lake systems, located in the delta of the Syr DaryaRiver.At the same time, as a result of the Aral Sea level fall, new coastal lakes appeared - former bays of the sea [3, 4]. As a result of the construction of the Aklak hydropower center (2009) on the Syr Darya River under the SYNAS program (Syr Darya Control and Northern Aral Sea), it was possible to fill the lake systems, including the coastal ones, in the lower courses of the Syr Darya River, that helped to maintain the biodiversity [4]. At the same time, birds, due to their mobility, were among the first to colonize water bodies in the process of restoration, and were excellent indicators of biodiversity [5-6]. The object of our study is Lake Cartma, the flood zone of the Large Aral Sea, in the early 1990's separated from the eastern part of the main reservoir. For 20 years ithas been periodically drained.The current hydrological state is supported by the Syr Darya River through the Karateren canal [1, 7].

From the moment of filling the lake systems of the Syr Darya delta, ornithological studies were conducted in the water area and the vicinity of the Northern Aral Sea, the Kamystybas, Akshatau, Aksai, and Kuan Darya lake systems, but the avifauna of coastal left-bank reservoirs was not taken into account [1-6].

The authors of this work carried out the bird counts on Lake Cartma, forming a part of the coastal leftbank lake system of the Syr Darya delta, in order to clarify the quantitative composition and nature of the avifauna of waders, in the process of restoring the ecological situation in the Aral Sea region.

\section{Methods}

The materials were collected during the migrationnesting period, in spring and summer of 2017. The studied area is a neighborhood and the very water area of Lake Cartma, a coastal left-bank system of lakes of the Syr Darya River delta, located $30 \mathrm{~km}$ east of the Northern Aral Sea, upstream of the Syr Darya River, in the Kyzylorda region of the Republic of Kazakhstan. The calculations were carried out according to the standard method [8], with allowance for open terrain [5]. 8-fold binoculars, photographic equipment were used in the work.

The collection of the material was carried out on the basis of the method of linear transects (route census) and the method of mapping (area census). The transect method was used to determine species composition and relative density of birds [8-10]. The method of mapping was used if necessary, to define 
the exact (or close to absolute) number of species, individuals for a certain area [10-11].

In the process of descriptionthe species density, a scale of scores of abundance was adopted [12] for 5 units:

1) very numerous species, with a population of 100-999 individuals per $1 \mathrm{~km}^{2}$;

2) numerous - 10-99 individuals;

3) common- 1-9 individuals;

4) rare - 0.1-0.9 individuals;

5) very rare - 0.01-0.09 individuals.

The share of species in the bird population was calculated by the formula:

$$
D=\frac{\text { Nspecies * } * 100 \%}{N},
$$

WhereNspeciesis the density of individuals of a certain type;

$\mathrm{N}$ - is the density of individuals of all bird species, recorded in the studied region.

Graduation of dominance degree, proposed by A.P. Kuzyakin [12], provided for three main units:

1. dominants - the number of the species individuals was from 10 to $100 \%$;

2. secondary - $1-9.9 \%$;

3. third-rate $-0.1-0.9 \%$.

In view of the presence in the route censuses of species, whose density indicators were outside the classification, we have added the following groups:
4. rare - $0.01-0.09 \%$
5 . very rare $-0.001-0.009 \%$.

Seasonality of the species staying is specified according to the publication of A.F. Kovshar [13], and expressed in alphabetic denominations. " $\mathbf{R}$ " is a sedentary species, which is reside at the surrounding areas and waters of Lake Cartma all year round; "B"- nesting species, whose nest, clutchesor chicks were found; "b" - nesting accidental or extremely rare; "M" - transient species, registered during the migration period; "m" - transient species, rarely or accidentally appeared during migration; "v" - is an extremely rare case of transition - a species not characteristic for a given territory; "A" - transient species, staying within the limits of Lake Cartmafor a summer period; "a" - is observed in summer, but rarely, "?"-is a doubt.

Types of avifauna are presented according to B.K. Shtegman [14].

Russian and Latin names of bird species, as well as the sequence of their location, are given according to the overview "Birds of Kazakhstan" [2, 15], with some changes and additions, according to the source of A.F. Kovshar [13], V.K. Ryabitsev et al. [16], and also [17-29].

\section{Results and Discussion}

Lake Cartma is steadily watered since 2009 exclusively in the warm season, has a relatively small water area $\left(7.0 \mathrm{~km}^{2}\right)$ and a depth $(1-2 \mathrm{~m})$ [7]. The central part of the reservoir is occupied by dense thickets of reeds and is an excellent place for the dislocation of anseriformes (shelduck, garganey teal, red-nosed duck) and rails (coot) [18-22]. The coastline is slightly indented, has a gentle slope, the soil cover is sand mixed with solonchaks [1].

Waders are represented by 5 families, 13 genera, 18 species, large species diversity is characteristic for the sandpiper family (Scolopocidae): quantitative composition - 8 genera, 11 species.

A total of 18 species of waders were defined, 1 (one) species of which is included in the Red Book of the Republic of Kazakhstan - sociable plover (Chettusialeucura), it was observed during the spring migration.

A favorite place for waders is the dry coastline, 10 meters long, and a strip of flooded coast along with a coastal shoal, about 100 meters wide, in other words, a littoral [1, 3-4]. The results of the waderscensus of Lake Cartma are given in Table 1.

Dry coast to the water's edge as a place of nesting and the nutritive base is used by the Norfolk plover (Burhinusoedicnemus), little ringed plover (Charadriusdubius), common plover (Vanellusvanellus), white-tailed lapwing (Vanellochettusialeucura), collared pratincole(Glareolapratincola). Black-winged stilt (Himantopushimantopus) makes a nest on the water or near the water, extracts food by wandering in shallow water [17, 22-25].

Green sandpiper (Tringaochropus), wood sandpiper (Tringaglareola), common greenshank (Tringanebularia), marsh sandpiper (Tringastagnatilis), common sandpiper (Actitishypoleucos), $\quad$ Terek sandpiper (Xenuscinereus), red-necked phalarope (Phalaropuslobatus), little stint (Calidrisminuta), broad-billed sandpiper (Limicolafalcinellus), grass snipe (Lymnocryptesminimus), common snipe (Gallinagogallinago) are observed during the migration [17, 26-29]. 
Table 1Waders of Lake Cartma and the Number of Individuals, Defined During the Route Census

\begin{tabular}{|l|l|l|l|}
\hline № & Species & Numberofindividuals & $\begin{array}{l}\text { Share from TNSS, } \\
\%\end{array}$ \\
\hline 1. & Norfolk plover (Burhinusoedicnemus) & 36 & 11 \\
\hline 2. & Little ringed plover (Charadriusdubius) & 4 & 1.2 \\
\hline 3. & Sociable plover (Chettusiagregaria) $(\mathrm{RB})$ & 1 & 0.3 \\
\hline 4. & Common plover (Vanellusvanellus) & 5 & 1.5 \\
\hline 5. & White-tailed lapwing (Vanellochettusialeucura) & 143 & 43.7 \\
\hline 6. & Black-winged stilt (Himantopushimantopus) & 82 & 25.1 \\
\hline 7. & Green sandpiper (Tringaochropus) & 15 & 4.6 \\
\hline 8. & Wood sandpiper (Tringaglareola) & 2 & 0.6 \\
\hline 9. & Common greenshank (Tringanebularia) & 1 & 0.3 \\
\hline 10. & Marshsandpiper(Tringastagnatilis) & 8 & 2.4 \\
\hline 11. & Common sandpiper (Actitishypoleucos) & 6 & 1.8 \\
\hline 12. & Terek sandpiper (Xenuscinereus) & 1 & 0.3 \\
\hline 13. & Red-necked phalarope (Phalaropuslobatus) & 8 & 2.4 \\
\hline 14. & Little stint (Calidrisminuta) & 1 & 0.3 \\
\hline 15. & Broad-billed sandpiper (Limicolafalcinellus) & 1 & 0.3 \\
\hline 16. & Grass snipe (Lymnocryptesminimus) & 2 & 0.6 \\
\hline 17. & Common snipe (Gallinagogallinago) & 1 & 0.3 \\
\hline 18. & Collared pratincole(Glareolapratincola) & 11 & 3.3 \\
\hline Total & & 328 & 100 \\
\hline
\end{tabular}

Note. TNSS-is the total number of suborder species; RB-is the species, listed in the Red Book of the Republic of Kazakhstan.

During the bird census (Table 1), we noted the predominance of white-tailed lapwing, this species is the Central Asian endemic in the composition of Mediterranean ornitho-geographical type, the share of lapwings in the total number of suborder species was 43.7\% (Table 2) [15].

As it is known, most waders are near-water species, and the species, defined by us, are also no exception, taking into account the physiographic location of Lake Cartma,as a part of the lake system of the Syr Darya River delta in the arid zone of Central Asia deserts $[4,17]$.
All waders without exception, mentioned in the framework of this study, belong to the entomophage species (insectivorous) according to the trophic group [3].

The current state of the avifaunal zoning of Northern Eurasia is reflected in the publication of T.K. Blinova, Yu.S. Ravkin [30], according to which the territory of our study is located within the boundaries of the following areas: a flat region of the western province of a desert subregion; Aralo-Balkhash district of the western province of the temperateisland subregion.

Table 2 Ornitho-Geographical Type of Avifauna Species, Suborder of Waders, in the Water Area and Adjacent Territory of Lake Cartma

\begin{tabular}{|l|l|l|l|}
\hline$№$ & Ornitho-geographical Type & Number of Species & Sharefrom TNSS, \% \\
\hline 1. & Mediterranean & 4 & 22,2 \\
\hline 2. & Mongolian & 1 & 5,6 \\
\hline 3. & European & 1 & 5,6 \\
\hline 4. & Siberian & 4 & 22,2 \\
\hline 5. & Arctic & 2 & 11,1 \\
\hline 6. & Transpalearctic & 6 & 33,3 \\
\hline \multicolumn{2}{|l|}{ Total } & 18 & 100 \\
\hline
\end{tabular}

Note. TNSS - is the total number of suborder species

In general, the population of waders of Lake Cartma belongs to a mixed ornitho-geographical type, where is the stratification of elements of different types
(Mediterranean, Mongolian, European, Siberian, Arctic) with a predominance of transpalearctic species (Table 2) [14, 31]. 
Table 3 The Distribution of Avifauna Species of the Waders' Suborder in the Water Area and the Adjoining Territory of Lake Cartma

\begin{tabular}{|l|l|l|l|l|}
\hline$№$ & $\begin{array}{l}\text { Letter } \\
\text { Identification }\end{array}$ & Description & $\begin{array}{l}\text { Number } \\
\text { Species }\end{array}$ & $\begin{array}{l}\text { of } \\
\text { TNSS, } \%\end{array}$ \\
\hline 1. & B & Nestingspecies & 6 & 33,3 \\
\hline 2. & M & Transientspecies & 2 & 11,1 \\
\hline 3. & M A & $\begin{array}{l}\text { Transient species, registered during the migration period } \\
\text { in spring and in autumn }\end{array}$ & 5 & 27,8 \\
\hline 4. & Ma & $\begin{array}{l}\text { Transient species, registered during the migration period } \\
\text { in summer, but rarely }\end{array}$ & 2 & 11,1 \\
\hline 5. & m a & $\begin{array}{l}\text { Transient species, rarely or accidentally appeared during } \\
\text { migration in summer }\end{array}$ & 2 & 11,1 \\
\hline 6. & a ?m & $\begin{array}{l}\text { Transient species, is observed in summer, in doubt, rarely } \\
\text { or accidentally appeared during migration }\end{array}$ & 1 & 5,6 \\
\hline \multicolumn{2}{|l|}{ Total }
\end{tabular}

Note. TNSS - is the total number of suborder species

For the most part, waders, noted during springsummer bird counts, are transient, migratory (common, rare) species.

\section{Conclusion}

According to the geographical position on the path of the main migration of birds, the structure of the shoreline and sloping littoral, the structure of the soil and food supply, Lake Cartmaoccupies an optimal position for waders. But at the same time, the reservoir in the system of lakes of the Syr Darya River delta, along with the Northern Aral Sea is at the stage of rehabilitation of the last regression of the Large Aral Sea. The low abundance of species diversity of waders can be explained by the relatively low diversity of phytocenoses of the coastal zone and the unstable regime of water content. Most of the limnophiles of Lake Cartmaare waders, represented by 18 species. Nesting species are prevailed by seasonality; other species visit the lake during the spring-autumn migrations and summer migrations. Comparison of the results of bird counts, conducted in the Aral Sea region, covering a period of about 200 years, shows that waders are one of the main species of avifauna, which basically adhere to the places of habitat and feeding, staying and distribution.

\section{Acknowledgements}

The work is performed according to the Russian Government Program of Competitive Growth of Kazan Federal University.

\section{References}

[1] Sihanova N.S., Rahimov I.I. Avifauna of lake systems in Syr Darya river delta (Cartmalake). // International Journal of Pharmacy \& Technology. Issue \#2, Vol. 8. 2016. - Pp. 14624-14633. ISSN: 0975-766X.

[2] Dolgushin I.A. Birds of Kazakhstan. Vol. 1.AlmaAta, 1960. - Pp. 7-22.

[3] Sihanova N.S., Rahimov I.I.Inhabitants and ecology of Lake Cartmabirds // Bulletin of the Peoples' Friendship University, series Ecology and Life Safety, 2016, №4. - Pp. 33-43
[4] Sihanova N.S., Rahimov I.I.Peculiarities of the ornitocene and phytocenosis of Lake Cartma in the North Aral restoration zone (results of the 2014 expedition) // Modern Science: Actual Problems of Theory and Practice. Series "Natural and Technical Sciences". 2016. №1. - Pp. 3-8.

[5] Berezovikov N.N. Materials to the avifauna of the avandeltaof the Syr Darya and the Small Aral Sea // Russian ornithological journal. 2012. Vol. 21, Express edition 775. Pp. 1619-1653.

[6] Berezovikov N.N. Materials to the avifauna of the Small Aral sea, the avandeltaof the Syr Darya, Akshatau and Kamystybas lake systems // Russian ornithological journal. 2014. Vol. 23, Express Edition 986. Pp. 1065-1087.

[7] Askarov A.G. Report on the hydrological state of the Syr Darya River, delta lake systems and the Aral Sea from May to July 2017 // IG RK, PEC. Kent Aiteke bi, 2017.24 p.

[8] RavkinYu.S. To the methodology of counting birds in forest landscapes // Nature of foci of tickborne encephalitis in the Altai. Novosibirsk: Nauka, 1967. Pp. 66-75.

[9] Bogolyubov A.S. The study of the species composition and number of birds by the method of route registration // Ecosystem. 1999. 8 p.

[10] Romanov V.V. The methods of studying the ecology of terrestrial vertebrates: quantitative counts: Textbook/ V.V. Romanov, I.V. Maltsev. - Vladimir: Publishing house of VladimirState University, 2005. Pp. 4-40.

[11] Medvedev N.V. Methods of quantitative counts of birds: Textbook for the students of ecologicalbiological faculty/ N.V. Medvedev. - Petrozavodsk: Publishing house PetrSU, 2013. - 32 p.

[12] Kuzyakin A.P. Zoogeography of the USSR // Transactions of Moscow Regional Pedagogical Institute n.a. N.K. Krupskaya. 1962. Vol. 109, №1. Pp. 55-59.

[13] Kovshar A.F. Revision of avifauna and modern list of birds of Kazakhstan // Ornithological bulletin of Kazakhstan and Central Asia. -Issue 1. - Almaty: MOS - UBPK - KACB, 2012. - Pp. 51-70. 
[14] Shtegman B.K. Fundamentals of the ornithogeographic division of the Palearctic// Fauna of the USSR. Birds.M.; L., 1938.Vol. 1, ed. 2. 156p.

[15] Gavrin V.F., Dolgushin I.A., Korelov M.N., Kuzmina M.A. Birds of Kazakhstan. Vol. 2.Under the general editorship of I.A. Dolgushin.Alma-Ata, $1962.780 \mathrm{p}$.

[16] Ryabitsev V.K., Kovshar A.F., Kovshar V.A.,Berezovikov N.N. Field determinant of birds of Kazakhstan. Almaty, 2014. 512p.

[17] Message S., Taylor D. Field Guide to the Waders of Europe, Asia \& North America. Christopher Helm London. 2005. 224 p.

[18] D.D. Harber. The birds of the Soviet Union// Vol.48. №06. - Pp. 268-276.

[19] Gavrilov E., Gavrilov A. The Birds of Kazakhstan// Tethys Ornitological Research, vol. 2. Almaty, 2005, - Pp. 1-228.

[20] Aye R. Schwiezer M., Roth T. Birds of Central Asia (Kazakhstan, Turkmenistan, Uzbekistan, Kyrgyzstan, Tajikistan and Afghanistan) - Field Guide. London, 2012.336 p.

[21] Klaus Malling Olsen, Hans Larsson. Gulls of North America, Europe, and Asia.Princeton University Press.Princeton and Oxford. 2004. 608p.

[22] Lars Svensson. Identification guide to European Passerines. Fourth, revised and enlarged edition. Stockholm. 1992. 368 p.
[23] Viktor P.Belik. The sociable lapwing in Eurasia: what does the future hold? // British Birds 98. September 2005. - Pp. 476-485.

[24] Rasmussen Pamela C. \& John C. Anderton. Birds of South Asia. The Ripley Guide. V. 1-2. Smithsonian Institution and Lynx Edicions. 2005 (second edition 2012). Vol. 1: 384 pp., Vol. 2: 688 p. [25] Wassink, A.\&G.J.Oreel. 2008. Birds of Kazakhstan: new and interesting data. Dutch Birding 30. 2008. Pp. 93-100.

[26] David T.Parkin, Martin Collinson, Andreas J. Helbig, Alan G. Knox and George Sangster. The taxonomic status of Carrion and Hooded Crows// British Birds 96. June 2003. - Pp. 274-290.

[27] Svensson L. Collins Bird Guide. 2-nd edit. Harper Collins Publishers Ltd. London. 2010. 446 p. [28] Svensson L., Grant P.J., Mullarney K., Zetterstrom D. Collins Bird Guide. The most complete Field Guide to the Birds of Britain and Europe. London, 1999.392 p.

[29] Kenneth Williamson. Birds and climatic change// Bird Study. 1975. - Pp. 143-164. 2009. DOI: $10.1080 / 00063657509476459$.

[30] Blinova T.K., RavkinYu.S. Ornitho-faunistic zoning of Northern Eurasia // Siberian Ecological Journal, 1 (2008), - Pp. 101-121.

[31] Sihanova N.S. Avifauna of lake Cartma // "Science in the modern information society" Materials of the VI Int. scientific-practical. Conf. North Charleston, USA.Vol. 2. 2015. - Pp. 19-20. 